\title{
GPBP1L1 Gene
}

National Cancer Institute

\section{Source}

National Cancer Institute. GPBP1L1 Gene. NCI Thesaurus. Code C101466.

This gene may be involved in transcriptional regulation. 